\title{
Study of Financial Management Policy on Company Value (Study of the Textile and Garment Industry on the Indonesia Stock Exchange Period 2013-2017)
}

\section{Chairul Anam}

Management Department, University of Trunojoyo Madura

\begin{abstract}
The purpose of this study was to determine the effect of financial management policies which include investment policy, debt policy, profit policy) on the value of the company in the textile and garment industry companies that are listed on the Indonesia Stock Exchange (IDX) for the period 2013-2017. The research method used was purposive sampling and obtained sample of 6 companies from population of 17 textile and garment industry companies that were listed on the Indonesia Stock Exchange (IDX) for the period 2013-2017. The analysis technique used is multiple linear regression analysis. Based on the results of the study show that investment policies partially have no significant effect on firm value, debt policy partially has a significant effect on firm value, earnings policy has a significant effect on firm value, then based on the coefficient of determination ( $r 2$ ) of $66.9 \%$ explained by independent variables namely: investment policy, debt policy, profit policy. While the remaining $33.1 \%$ is explained by other variables not examined in this study, for example macroeconomic conditions, capital structure, company growth.
\end{abstract}

Corresponding Author:

Chairul Anam

Chairul.anam199@gmail.com

Received: 30 December 2019 Accepted: 29 January 2020 Published: 6 February 2020

Publishing services provided by Knowledge $\mathrm{E}$

(c) Chairul Anam. This article is distributed under the terms of the Creative Commons

Attribution License, which permits unrestricted use and redistribution provided that the original author and source are credited.

Selection and Peer-review unde the responsibility of the 6 th ICOEN 2019 Conference Committee.
Keywords: Investment policy, debt policy, profit policy, firm value.

\section{Introduction}

Textile and garment needs in Indonesia from time to time show significant development because Indonesia now Indonesia has begun to become the center of world fashion even designers from other countries are working with Indonesian designers because the innovations produced by Indonesian designers attract the world's attention even Indonesia's wealth for batik and weaving cloth is worldwide. Of course designers continue to innovate in producing clothing, veils, pants and more.

The main objective of companies listed on the Indonesia Stock Exchange is to maximize the welfare of shareholders. To achieve the goals of the company, many are influenced by financial management policies that are proxied with investment 
policies, debt policies and profit policies. Shareholder value will increase if the value of the company increases which can be seen from the high return on investment to shareholders. One way to increase the value of a company is that the company must be listed on the Indonesia Stock Exchange (IDX), making it easier for prospective investors to see the company's finances. In addition, the competition that arises requires companies to further improve their performance and innovate with their products so that they are better known by the public (Pratama and Wiksuana, 2016). To improve performance and product innovation, companies need more funds.

An important decision in the company is an investment decision. Wahyudi et al., (2016) investment decisions related to the results of profits obtained by the company in the future. The purpose of the statement Investment decisions have an important role because in achieving company goals will be produced through the company's investment activities. The decision to allocate capital into investment proposals whose benefits are realized in the future must be considered carefully. Because the benefits obtained in the future are full of uncertainty and contain risks. In investing a company must be able to produce maximum profits, with efficient use of resources. So the company will get maximum profits so that it will gain the trust of potential investors to invest. The higher the company's profits, the higher the prosperity that the company owner receives. In Wahyudi's research, Chuzaimah and Sugiarti (2016) say that investment decisions (PBV) have a positive effect and a positive relationship to firm value (PBV).

Debt policy is a policy carried out by the company to fund its operations using financial debt (Nainggolan and Listiadi, 2014: 868). Debt policy will increase the value of the company because the interest burden of debt can reduce the tax that must be paid by the company. The debt policy taken by the company is also related to the company's ability to repay debt and interest expenses. The greater the debt, the greater the likelihood that the company will not be able to repay debt and interest in the future, thereby increasing the company's risk of liquidation and a decrease in company profits due to having to pay debts and interest expenses. In the study of Nainggolan and Listiadi (2014), it was revealed that debt policy had no effect and had a negative relationship to firm value. While the research of Pertiwi, Tommy and Tumiwa (2016) says that debt policy simultaneously has a significant effect on firm value.

Profitability is one of the important things in company value. Fahmi (2013: 80) profitability measures management effectiveness as a whole as indicated by the size of the level of profits obtained by the company. Good company prospects are shown by high profitability, so there is a positive response from investors and the value of the company will increase. In investing, investors must consider the profit of the company 
which has a high profit, but investors must remain cautious in determining investment decisions because if it is not right, the investor will lose profits even all the initial capital invested in the company. For this reason, investors must be careful and gather complete information in assessing which companies to choose to invest in order to minimize future risks. Profitability is the result obtained through management efforts on funds invested by shareholders and also reflects the distribution of profits that are the rights of shareholders (Kusuma, 2015: 2). The results of Warouy, Nangoy and Saerang's (2016) study revealed that there was no effect of profitability variables on firm value.

As an illustration of the Progress of the Textile and Garment Industry Period 20102014 (in US \$) as in the table below

TABLE 1: Data on Sub-groups of results of the textile and garment industries 2010-2014 Period (in US \$).

\begin{tabular}{|l|c|c|c|c|}
\hline \multirow{2}{*}{ Name } & \multicolumn{5}{|c}{ year } \\
\hline & $\mathbf{2 0 1 1}$ & $\mathbf{2 0 1 2}$ & $\mathbf{2 0 1 3}$ & $\mathbf{2 0 1 4}$ \\
\hline Bonden woven fabric & 2.609 .750 & 2.985 .189 & 2.953 .432 & 4.166 .307 \\
\hline yarn & 698.058 .720 & 844.119 .508 & 985.912 .030 & 986.070 .617 \\
\hline apparel & 246.668 .330 & 276.164 .263 & 339.768 .032 & 322.467 .553 \\
\hline Other textils & 718.831 .442 & 721.545 .800 & 753.395 .652 & 768.957 .470 \\
\hline
\end{tabular}

Data Source: Kemenperin.go.id

From table 1 shows data from the textile and garment subgroup for the period 20102014. In table 1.1 it is known that the results of the Textile and Garment Industry for the period 2010-2014 experienced growth each year, except that in certain years it decreased but not significantly. This is interesting to study because the development of the results of the Textile and Garment Industry each period increases. When the results of the Textile Industry and Garment increase, it will increase the value of the company. From some of the results of research on financial management policy on corporate value that is proxied by investment policy, debt policy and profit policy there are linkages as stated by some researchers, the results of Wahyudi, Chuzaimah and Sugiarti (2016) say that investment decisions have a positive positive effect on firm value as well as the results of the research by Pertiwi, Tommy and Tumiwa (2016), that investment decisions partially have a significant effect on firm value.

The results of Pertiwi's research, Tommy and Tumiwa (2016) say that debt policy partially has no significant effect on firm value, whereas in the research of Nainggolan and Listiadi (2014) revealed that debt policy does not affect the value of the company. 
The results of Suffah and Riduwan (2016) revealed that the profit / profitability policy has a significant positive effect on firm value, as well as the Ulum study (2015) also revealed that profitability has a significant effect on firm value.

Based on the description above, the hypothesis is formulated as follows:

$\mathrm{H} 1$ : investment policy affects the value of the company

$\mathrm{H} 2$ : debt policy affects the value of the company

H3: profit policy affects the value of the company

\section{Methods and Equipment}

\subsection{Research Methods}

The object of this research was carried out on Textile and Garment Industry companies listed on the Indonesia Stock Exchange (IDX). The time used in this study is the period 2013-2017, with data obtained from the Indonesia Stock Exchange (IDX) accessed through the internet site (www.idx.co.id)

\subsubsection{Population}

Sugiyono (2015: 80) population is a generalization region consisting of: objects or subjects that have certain qualities and characteristics set by researchers to be studied and then conclusions drawn. The population in this study is that there are 17 Textile and Garment Industry companies listed on the Indonesia Stock Exchange (IDX) for the period 2013-2017.

\subsubsection{Sample}

Sugiyono (2015: 81) the sample is part of the number and characteristics possessed by the population. The method used in this study was purposive sampling, obtained by 6 textile and garment industry companies listed on the Indonesia Stock Exchange for the period 2013-2017.

\subsubsection{Data source}

Secondary data is data obtained from sources that indirectly provide data to data collectors, for example through other people or documents (Sugiyono, 2015: 137). 
Data analysis technique

1. Test of Classical Assumptions

a. Normality test

b. Multicollinearity Test

c. Heteroscedasticity Test

d. Autocorrelation Test

2. Multiple Linear Regression

3. Test $\mathrm{t}$

4. Determination Test

\section{Results}

From the results of multiple linear analysis data obtained the equation of multiple regression models as follows:

$$
Y=-0,977+4,040 \times 1-0,345 \times 2+1,410 \times 3+0,059 \times 4+e
$$

TABLE 2: Result t test.

\begin{tabular}{|l|c|c|}
\hline Independent Variable & $\mathrm{t}_{\text {count }}$ & Sig. \\
\hline Investment Decision (PER) & 0,128 & 0,899 \\
\hline Debt Decision (DER) & $-3,621$ & 0,001 \\
\hline Profitability Decision (ROE) & 6,047 & 0,000 \\
\hline
\end{tabular}

Data source: Print out spss

Based on the results of the $t$ test, it can be concluded as follows:

Based on the results of the $t$ test shows the results of tcount and ttable for investment decisions (PER) of $0.128<1.70814$ with a significant level of $0.899>0.05$. From these results it can be concluded that the investment decision variable (PER) partially has a positive and not significant effect on firm value (PBV) in the Textile and Garment Industry companies listed on the Indonesia Stock Exchange (BEI) for the period 2013-2017.

Based on the results of the $t$ test showing the results of tcount and ttable for debt policy (DER) of $-3.662<1.70814$ with a significant level of $0.001<0.05$. From these results it can be concluded that the debt policy variable (DER) partially has a negative and significant effect on firm value (PBV) on Textile and Garment Industry companies listed on the Indonesia Stock Exchange (IDX) for the period 2013-2017. 
Based on the results of the $t$ test showing the results of tcount and ttable for profitability $(\mathrm{ROE})$ of $6.047>1.70814$ with a significant level of $0.000<0.05$. From these results it can be concluded that the variable profitability (ROE) partially has a positive and significant effect on firm value (PBV) in the Textile and Garment Industry companies listed on the Indonesia Stock Exchange (IDX) for the period 2013-2017.

\section{Discussion}

Furthermore, the discussion is more in depth as stated by Pertiwi, Tommy and Tumiwa (2016: 1370). Investment decisions are a very important factor in the company's financial function, where the higher the investment decision (PER) set by the company, the higher the company's opportunity to obtain returns or a large rate of return. The purpose of investment decisions is to obtain high profits with certain risks. From the high profits and the risks that can be managed well, it is expected that it will increase the value of the company, which also means increasing the prosperity of shareholders (Faridah and Kurnia, 2016: 3). The company has a high investment decision (PER) that is able to attract the attention of investors to invest. Investment decisions (PER) are related to the profits obtained by the company in the future. The higher the investment decision (PER), the higher the value of the company, if the profits obtained by the company increase then the value of the company will increase. That way investors are attracted to the company. When many investors invest in the company, then the stock price will increase, so the value of the company will increase.

The relationship of variable debt to firm value according to Pertiwi, Tommy and Tumiwa (2016: 1370) debt policy is a company policy about how far the company uses debt as its funding source. The use of debt policies chosen by the company is used to develop the company and increase the value of the company. The company is considered risky if it has a large portion of debt, but if the debt can produce maximum profits, then the debt policy will be able to increase the value of the company. On the other hand debt will add a fixed burden regardless of the amount of income. The greater the debt, the higher the level of bankruptcy because the company is unable to pay the debt and interest. The management must pay attention to the use of debt, because the large amount of debt can reduce the value of the company (Nainggolan and Listiadi, 2014: 876). The thing that must be considered by the company is the level of corporate debt every year because if the debt continues to increase, it needs to worry about liquidation because the company is unable to pay the debt and interest expense. According to Rizqia, Aisjah and Sumiati (2013: 123) Profitability is a measurement of 
management effectiveness based on the rate of return from sales and investment. Profitability is the company's ability to generate profits (Sabrin, 2016: 85). Investors who have shares are interested in making a profit, the higher the company's ability to generate profits, the greater the expected rate of return to investors, making the value of the company better (Purwohandoko, 2017: 10). For this reason, the company must have a target every year and must reach the target so that the profit generated increases optimally. The greater the profitability (ROE), the company managers succeed in managing the company's capital to a minimum to produce maximum profits.

Based on the results of the $t$ test showing the results of tcount and ttable for profitability (ROE) of $6.047>1.70814$ with a significant level of $0.000<0.05$. Based on the data processing results obtained profitability represented by Return on Equity (ROE) shows that profitability (ROE) partially has a positive and significant effect on firm value (PBV). Positive coefficient values indicate profitability (ROE) has a relationship that is in the same direction and significant to the value of the company (PBV). If the value of profitability (ROE) increases, it will increase the value of the company (PBV) with a significant effect, conversely if the value of profitability (ROE) decreases it will reduce the value of the company (PBV) with a significant influence

TABLE 3: Coefisien Determinasi test $\left(R^{2}\right)$.

\begin{tabular}{|c|c|c|c|}
\hline Model & $\mathrm{R}$ & $\mathrm{R}$ Square & $\begin{array}{c}\text { Adjusted } \mathrm{R} \\
\text { Square }\end{array}$ \\
\hline 1 & $.818^{a}$ & .669 & .616 \\
\hline
\end{tabular}

Data source: Print out spss

Based on the test results of the coefficient of determination (R2) obtained the coefficient of determination (R2) of 0.669. These results mean that there is a contribution of $66.9 \%$ of the independent variables, among others: investment decisions (PER), debt policy (DER), profitability (ROE) in explaining the dependent variable, namely firm value (PBV). The ability of independent variables in explaining the dependent variable is $66.9 \%$ while the remaining $33.1 \%$ is explained by other variables not examined in this study, for example macroeconomic conditions, company growth and others.

\section{Conclusion}

Based on data analysis and discussion of research results, conclusions can be drawn as follows: Investment decisions (PER) partially have a positive and not significant effect on firm value (PBV). Debt policy (DER) partially has a negative and significant effect on firm 
value (PBV). Partial profitability (ROE) has a positive and significant effect on firm value (PBV). Test coefficient of determination $\left(R^{2}\right)$ of 0.669 . The results of this study mean that there is a contribution of $66.9 \%$ of the ability of the independent variable to explain the dependent variable, while the remaining $33.1 \%$ is explained by other variables not examined in this study, for example macroeconomic conditions, company growth and others.

\section{References}

[1] Fahmi, Irham. (2013). Introduction to Financial Management Theories and Questions. Bandung: Alfabeta.

[2] Faridah, Nur dan Kurnia, (2016). Effect of Investment Decisions, Funding, Dividend Policy, Interest Rates on Company Value, Vol. 5 No. 2: 1-15.

[3] Halim, Abdul. (2015). Business Financial Management "Concepts and Applications". Jakarta: Mitra Wacana Media.

[4] Kamaludin. (2011). Financial Management "Basic Concepts and Their Application". Bandung: CV. Mandar Maju.

[5] Kasmir. (2013). Financial Statement Analysis. Jakarta: PT. Raja Grafindo Persada.

[6] Kusuma, Any, Widya, (2015). Analysis of the Effect of Profitability, Investment Decisions and Debt Policy on Corporate Value (In Property, Real Estate \& Building Construction Companies, which are Listed on the Indonesia Stock Exchange Period 2010-2015). Paper, Trunojoyo Madura University Postgraduate Program.

[7] Margaretha, Farah. (2014). Fundamentals of Financial Management. Jakarta: PT. Dian Rakyat.

[8] Nainggolan, Subaraman, Desmon D.A. dan agung Listiadi, (2014). The Effect of Debt Against Firm Value With Dividend Policy As Moderation Variable, Vol. 2 No. 3:868879.

[9] Najmudin. (2011). Financial Management and Actualization of Modern Shariah. Yogyakarta: C.V Andi Offset.

[10] Pertiwi, Putri Juwita, Parengkuan Tommy dan Johan R. Tumiwa. (2016). Effect of Debt Policy, Investment Decisions and Profitability Against the Value of Food Beverages Companies listed on the Indonesia Stock Exchange, Vol. 4 No. 1: 1369-1380.

[11] Pratama, I Gusti, B.A dan I Gusti Bagus Wiksuana, (2016). Effect of Company Size and Leverage on Firm Value with Profitability as a Mediating Variable,, Vol. 2 No. 2: 1338-1367. 
[12] Purwohandoko, (2017). The Influence on Firms's Size, Growth and Profitability on Firm Value with Capital Structure as the Mediator: A Study on the Agricultural Firms Listed in the Indonesian Stock Exchange. Internasional Journal of Economics and Finance, Vol. 9 No. 8: 103-110.

[13] Ratnasari, Linda dan Budiyanto, (2016). Effect of Leverage, Liquidity, Company Size on Profitability of Automotive Companies on the Indonesia Stock Exchange (IDX), Vol. 5 No. 6: 1-15.

[14] Rizqia, Dwita Ayu, Siti Aisjah dan Sumiati, (2013). Effect of Managerial Ownership, Financial Leverage, Profitability, Rirm Size, and Investment Opportunity on Dividend Policy and Firm Value. Research Journal Finance and Accounting, Vol. 4 No. 11: 120-130.

[15] Romlah, Dwi, 2016. Effects of Return On Assets (ROA), Return On Equity (ROE), Company Age (AGE) and Company Size (SIZE) Against Returns After Initial Public Offering (IPO) on Manufacturing Companies Registered in Indonesia Stock Exchange (IDX) Period 2010-2014. Paper, Program Pascasarjana: Universitas Trunojoyo Madura.

[16] Rumondor, Regina, Maryam Mangantar dan Jacky S.B. Sumarauw, 2015. The Effect of Capital Structure, Company Size and Company Risk on Company Value in the Plastic and Packaging Sub Sector at IDX, Vol. 3 No. 3: 159-169.

[17] Sabrin, et al., (2016). The Effect of Profitability on Firm Value in Manufacturing Company at Indonesia Stock Exchange. The Internasional Journal of Engineering and Science (IJES), Vol. 5: 81-89.

[18] Santoso, Singgih. (2015). Mastering Parametric Statistics.. Jakarta: PT. Gramedia.

[19] Suffah, Roviqotus dan Akhmad Riduwan, (2016). Effect of Profitability, Leverage, Company Size and Dividend Policy on Firm Value, Vol. 5 No. 2: 2-17

[20] Sugiyono. (2007). Statistics for Research. Bandung, CV. Alfabeta.

[21] Sugiyono. (2015). Quantitative, Qualitative, and R\&D Research Methods.. Bandung: CV. Alfabeta.

[22] Ulum, Achmad, Saiful, (2015). The Influence of Profitability and Capital Structure on Firm Value (Study on Manufacturing Industries Listed at Indonesia Stock Exchange for Periode 2008-2012), Vol. 14 No. 1:79-97.

[23] Wahyudi, Henri, Dwi, Chuzaimah dan Dani Sugiarti, (2016). Influence of Company Size, Profitability, Dividend Policy and Investment Decisions on Company Value (Study of Use of the Lq-45 Index 2010-2014 Period), Vol.1 no. 2: 156-164. 
[24] Warouw, Christina, Sintje Nangoy dan Ivonne S. Saerang, (2016). The Effect of Working Capital Turnover and Profitability on Company Value in Pharmaceutical Companies on the Indonesia Stock Exchange, Vol. 16 No. 02: 366-375. 